\title{
Hagyomány és modernitás innovációja egy tradicionális felsőokta- tási intézményben: 25 éves az Alkalmazott Egészségtudományi és Egészségfejlesztési Intézet (2020. szeptember 1.)
}

\author{
The Innovation of Tradition and Modernity in a traditional higher education \\ institute: The 25th Anniversary of the Institute of Applied Health Sciences \\ and Health Promotion (1st of September, 2020)
}

\begin{abstract}
Szerzők: $\quad$ Benkő Zsuzsanna $\bigotimes$, Tarkó Klára
Szegedi Tudományegyetem, Juhász Gyula Pedagógusképző Kar,

Alkalmazott Egészségtudományi és Egészségfejlesztési Intézet
\end{abstract}

Beküldve: $\quad$ 2020. 08. 21.

doi: $\quad$ 10.24365/ef.v61i3.616

Kulcsszavak: egészségfejlesztés; mentálhigiéné; lelki egészségfejlesztés; holisztikus; multidiszciplináris

Keywords: health promotion; mental hygiene; mental health promotion; holistic; multidisciplinary

1991-ben a Szentgyörgyi Albert Orvostudományi Egyetem néhány munkatársa - pszichiáterek, pszichológusok, szociológusok stb. - úgy érezték, hogy 20-25 éves szakmai munkatapasztalat mellett érdemes valami újabb, talán szintén nagyon hasznos területet megismerni, mely terület olyannyira újdonságnak számított Magyarországon, hogy a Health Promotion kifejezés magyarítása is e munkacsoport vezetője, Prof. Dr. Benkő Zsuzsanna nevéhez fúződik. Elindultak hát, mint a népmesében, meglelni az álmaik megvalósítását lehetővé tévő szegedi felsőoktatási intézményt. Mentek, mendegéltek, míg elértek az akkor még Juhász Gyula Tanárképző Főiskolához. Először rövidebb, érzékenyítő képzésekkel indítottak hősnőink, végül 1995ben révbe értek. Prof. Dr. Benkő Zsuzsanna vezetésével megalakult egy pár négyzetméteres irodában az Alkalmazott Egészségtudományi Tanszék három oktató és egy adminisztrátor részvételével. A formáció sikerre volt ítélve. Tíz év elteltével már hét oktató egy oktatásszervező, és egy adminisztrátor munkatárs látta el mindazt a feladatot, amelyet az akkorra 834 főre duzzadt hallgatói létszám meg- kívánt. ${ }^{1}$ Lássuk hát, mi vonzotta annyira az érdeklődő hallgatókat [1. ábra]!

Intézetünk kedvenc analógiája a fa, különösen, ha ágas-bogas gyökerei, nagy lombkoronája van és roskadozik a gyümölcstől. 1991-ben 30 órás egészségnevelési kurzus indult a Juhász Gyula Tanárképző Főiskolán, melynek tapasztalatai alapján 1992-ben, egy egyhetes országos tanártovábbképző akadémiára került sor. A nemzetközi rendezvényen mintegy 300 fő vett részt. Az előadások anyagát mai napig használható kötet tartalmazza. Az előadásokat pszichológus, gyermekorvos, pszichiáter, filozófus, szociológus, lelkipásztor tartotta. Ugyancsak 1992ben kezdődött el az Egészségfejlesztő mentálhigiénikus posztgraduális képzés akkreditálása és maga a képzés is: A cél nem önálló szakma kialakítása volt, hanem az, hogy a résztvevők multiplikátorokként terjesszék, és hivatásukba integráltan alkalmazzák a megszerzett multidiszciplináris, komplex elméleti és gyakorlati tudást. Így megvalósították a szektorok közötti átjárhatóságot és közös nyelv kialakításával megalapozták a hálózatépítés lehetőségét. 
1. ábra: Az Alkalmazott Egészségtudományi és Egészségfejlesztési Intézet képzései 1991 és 2004 között

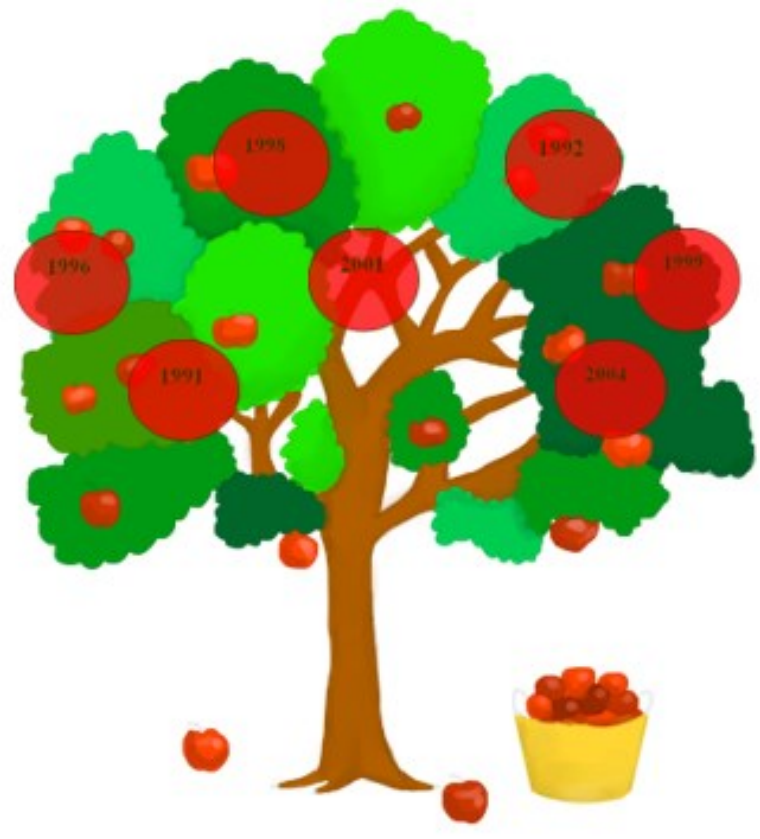

Forrás: Saját szerkesztés
1991 - 30 órás egészségnevelési kurzus (JGYTF)

1992 - Országos Tanártovábbképző Akadémia (1 hét, 300 résztvevö)

$1992 \quad$ - Egészségfejlesztö mentálhigiénikus posztgraduális képzés (2005-ig 2008 fö kiképzett)

1996 - nappali tagozatos, föiskolai szintü egészségtan tanár szak

30 órás regionális képzések segitõ foglalkozásúak számára (10 település, 416 fó ) )

1998 - Egészségnevelés mentálhigiéné 120 órás továbbképzés, pedagógusoknak

1999 - $\quad$ Egészségfejlesztő mentálhigiénikus pedagógus szakvizsga 2001 - Egyetemi szintü egészségtan tanár szak

2004 - kisebbség-koordinátor pedagógus szakvizsgára felkészitö program
Jelentkezőink az egészségügy, a szociális ellátás, az oktatás, az államigazgatás területein dolgozó különböző alapvégzettségű szakemberek voltak. 1995 szeptemberétől indult a nappali tagozatos egészségtan tanár szak curriculumának akkreditációja. 1997-ben a szak akkreditációs folyamata lezárult, így 1998 szeptemberétől elindulhatott a nappali tagozatos képzés. A tanárszakos munkálatok elindulásával egy időben a Dél-alföldi régióban 30 órás képzéseket indítottunk segítő foglalkozásúak számára - mellyel olyan szakembereket kívántunk képezni, akik képviselik a korszerű egészség-megközelítést a munkájukban, képesek a munkahelyükön a szükséges egészségfejlesztő információátadásra és együttműködő partnerei a professzionális egészségfejlesztő mentálhigiénikus szakembernek, illetve az egészségtan tanárnak, vagyis az egészségfejlesztő teamek hasznos tagjai. 1998-ban az Egészségnevelés, mentálhigiéné elnevezésű, négy darab 30 órás modulból álló, összesen 120 órás tanártovábbképzést szintén multidiszciplináris team dolgozta ki. Cél: a köznevelésben - óvodában, általános iskolában, szakképző intézményben, gimnáziumban - dolgozó pedagógusok szélesebb rétegei számára is felkínálni szemléletformáló, gyakorlatorientált kurzusokat. A 4 modul az Egészséges életmód
(30 óra), a Lelki egészségvédelem (30 óra), az Egészzséges társadalom (30 óra), és a Konfliktuskezelő tréning (30 óra) voltak. 2001-ben benyújtottuk az egyetemi szintű, 5 éves egészségtan tanár szak akkreditációs anyagát, melynek indítására 2002-ben kaptuk meg az engedélyt. Az első egyetemi évfolyam a 2004-2005-ös tanévben kezdte meg tanulmányait, együttmúködve a Szegedi Tudományegyetem Általános Orvostudományi Karával. 2004-ben pedig - nemzetiségi, roma, pedagógus - fókuszcsoportos vizsgálatokra és külföldi tanulmányutakra alapozva megalapítottuk a kisebbség-koordinátor pedagógus szakvizsgára felkészítő programot.

Ugyancsak 1995-ben kezdődött meg az Országos Mentálhigiénés Mozgalommal való szoros együttműködésben a kihelyezett tagozatok országos hálózatának kialakítása is. Ezt a tevékenységet az országos mentálhigiénés mozgalom keretében létrejött Mentálhigiénés Programiroda is segítette, amelynek akkori vezetője Prof. Dr. Benkő Zsuzsanna volt. A Regionális Mentálhigiénés Programirodák a terepgyakorlatok szervezésével kapcsolódtak a képzéshez. A képzésbe bekapcsolódó alközpontok: [2. ábra] 
- Pécsi Tudományegyetem, Egészségtudományi Főiskolai Kar, Pécs

- Pécsi Tudományegyetem, Pedagógiai Főiskolai Kar, Szekszárd

- Nyíregyházi Főiskola, Tanárképző Főiskolai Kar, Nyíregyháza

- Miskolci Egyetem, Bölcsészettudományi Kar, Miskolc
- Széchenyi István Egyetem, Győr

- Debreceni Református Tanítóképző Főiskola, Debrecen

- Berzsenyi Dániel Főiskola, Szombathely

- Semmelweis Egyetem ÁOK, Pszichiátriai és Pszichoterápiás Klinika, Budapest

- Veszprémi Egyetem, Veszprém

\section{2. ábra: Hálózatban történő épitkezés}

\section{Az Egészségfejlesztö-mentálhigiénikus posztgraduális szakirányú} továbbképzések helyszínei és az első évfolyamok indításának időpontjai

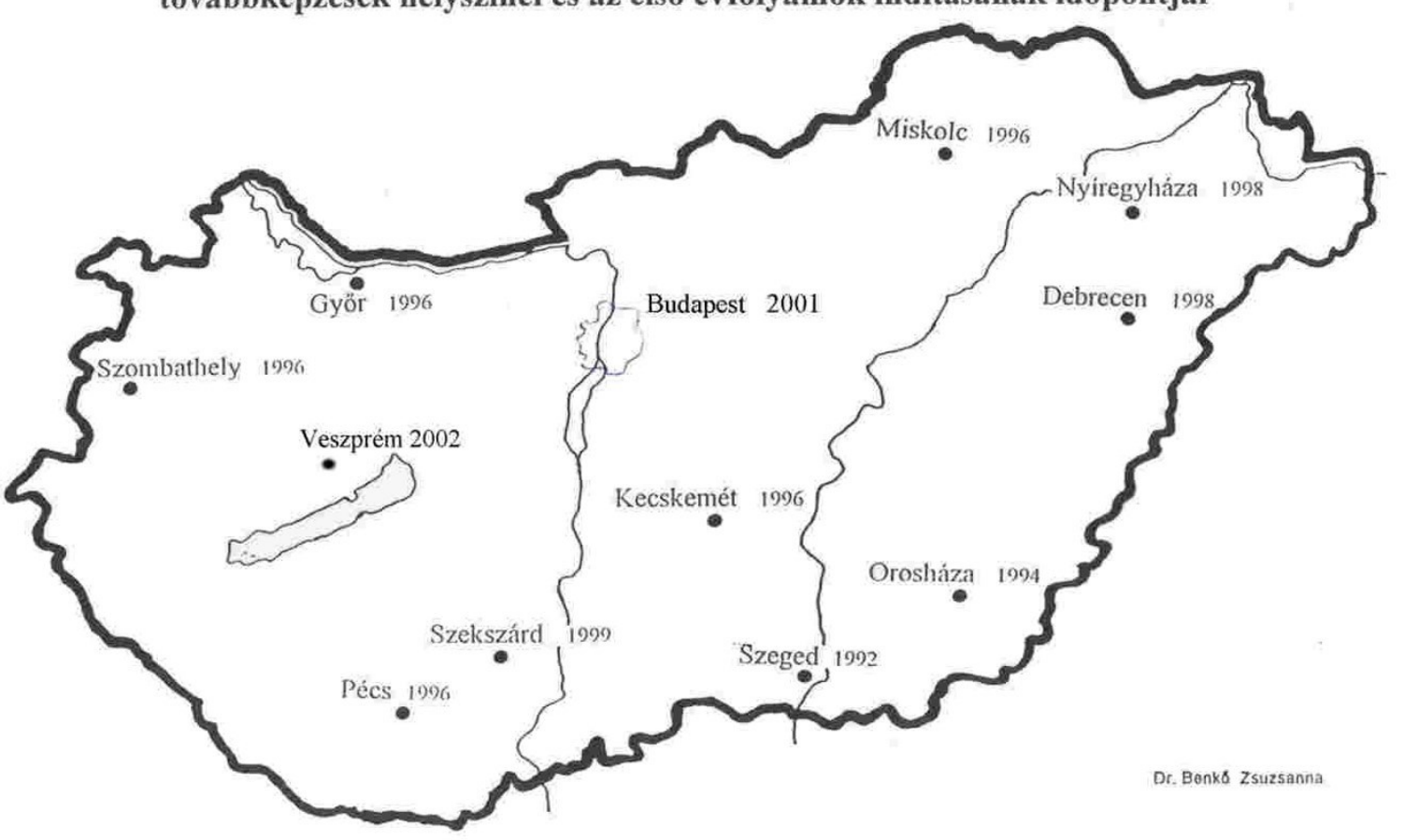

Forrás: Saját szerkesztés

A képzések mellett modellprogramok létrehozása, megvalósítása szolgálta - a felhalmozott tudás és tapasztalat alapján - a Dél-alföldi Régió egészségesélyének javítását. ${ }^{1}$

1999. június 23.-án alakult meg a Szegedi Akadémiai Bizottság Orvostudományi Szakbizottság Egészségfejlesztési Munkabizottsága, mely minden évben rendszeresen a Tudomány ünnepe alkalmából az egészségfejlesztés szerteágazó témáiból - tudományos felolvasóülést tart. Az eltelt 21 év alatt 20 felolvasóülést/konferenciát tartottunk és a Munkabizottság jelenleg 38 fő állandó tagot számlál. A Munkabizottság alapító elnöke Prof. Dr. Benkő
Zsuzsanna, akitől 2019-ben Dr. habil. Tarkó Klára vette át az elnöki teendőket. A felolvasóüléseket 2005 óta kíséri az akkor még Alkalmazott Egészségtudományi Tanszék által megalapított Egészségfejlesztésért emlékérem [3. ábra] ünnepélyes keretek között történő átadása. Az elismerést évente 2 olyan - hazai, vagy külföldi, különböző szakterüle ten tevékenykedő szakember kapja meg, aki sokat tett az egészségfejlesztés ügyének előmozdításáért. 2005 óta 31 szakember részesült a megtiszteltetésben. A kitüntetettek neve Intézetünk honlapján megtekinthető: http://www.jgypk.hu/tanszek/alkegeszseg/01 IntezetMenu/06Emlekerem/emlekerem.html 


\section{3. ábra: Egészségfejlesztésért Emlékérem (Fritz Mihály kisplasztikája)}

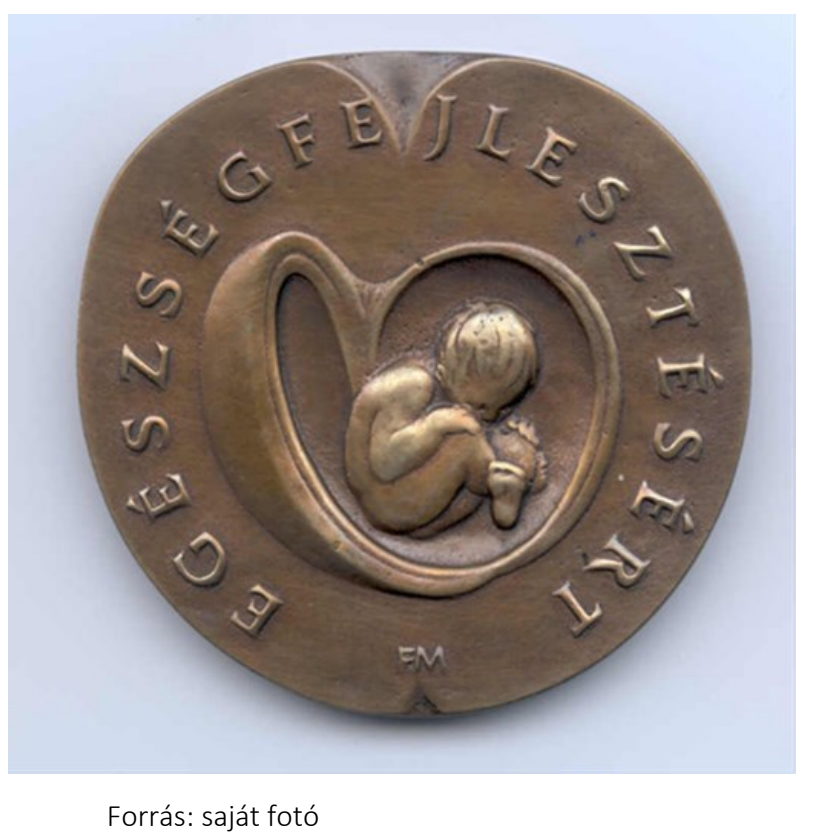

'Most már hátradőlhetünk és koccinthatunk egy finom vörösborral'. Valaki azonban föntről úgy gondolta, nem hagyom, hogy ezek a nagyszerü szakemberek ellustuljanak. Megérkezett az un. Bologna folyamat, amely az Európai Felsőoktatási térség egyetemein és főiskoláin, az angolszász felsőoktatási rendszer példájára alapozva átstrukturálta képzési rendszerünket. Jött a furcsán hangzó bachelor és master. Az új rendszer szerinti első képzések 2006. szeptember 1-jétől indultak útjukra, elindítva a hagyományos képzési struktúra felbomlását és a létező főiskolai és egyetemi szakok többségének fokozatos kivonulását. ${ }^{1,2}$

Eljött az a pillanat, amikor egy tanszéki karácsonyi ünnepségen Benkő Professzor Asszony kijelentette: Számunkra mindez azt jelentette, hogy a fácskánkról lehullott néhány alma, de ez nem szegte kedvünket. Csapatunk azonnal alkalmazkodott az új feltételekhez és újabb szakalapításokba és indításokba kezdett, melyek az alábbiak voltak:

2006 - Rekreációszervezés és egészségfejlesztés alapképzési szak (Rekreációszervező, Egészségfejlesztő, Kisebbség egészségkoordinátor specializációkkal)

2008 - Egészségfejlesztés tanár master

2010 - Egészségfejlesztő mentálhigiéné szakirányú továbbképzési szak
2010 - Egészségfejlesztő mentálhigiénikus pedagógus szakvizsgára felkészítő szakirányú továbbképzési szak

2011 - Egészségfejlesztő kisebbségkoordinátor szakirányú továbbképzési szak

2011 - Egészségfejlesztő kisebbségkoordinátor pedagógus szakvizsgára felkészítő szakirányú továbbképzés

2015 - Stíluskommunikátor szakirányú továbbképzési szak

2019 - Mentálhigiénés közösség és kapcsolatépítő mesterképzési szak

A képzési rendszer átalakulását követte az immár a Szegedi Tudományegyetem keretei között működő Juhász Gyula Pedagógusképző Kar struktúrája is, ez számunkra azt jelentette, hogy tanszékünk intézeti rangra emelkedett. Az Intézet az egészségfejlesztés négy alappilléréből hármat (szociológia, pszichológia, pedagógia) szakcsoport szervezeti formában szakembergárdájával biztosított, a medicina területeit az SZTE Általános Orvostudományi Karral való - továbbra is kiváló - együttmúködésben valósítjuk meg a kezdetektől folyamatosan. A JGYPK és egyetemünk más karainak intézetei is biztosítják az oktatáshoz, kutatáshoz szükséges szakembereket. [4. ábra] 
4. ábra: Az Alkalmazott Egészségtudományi és Egészségfejlesztési Intézet struktúrája 2007-2015-ig

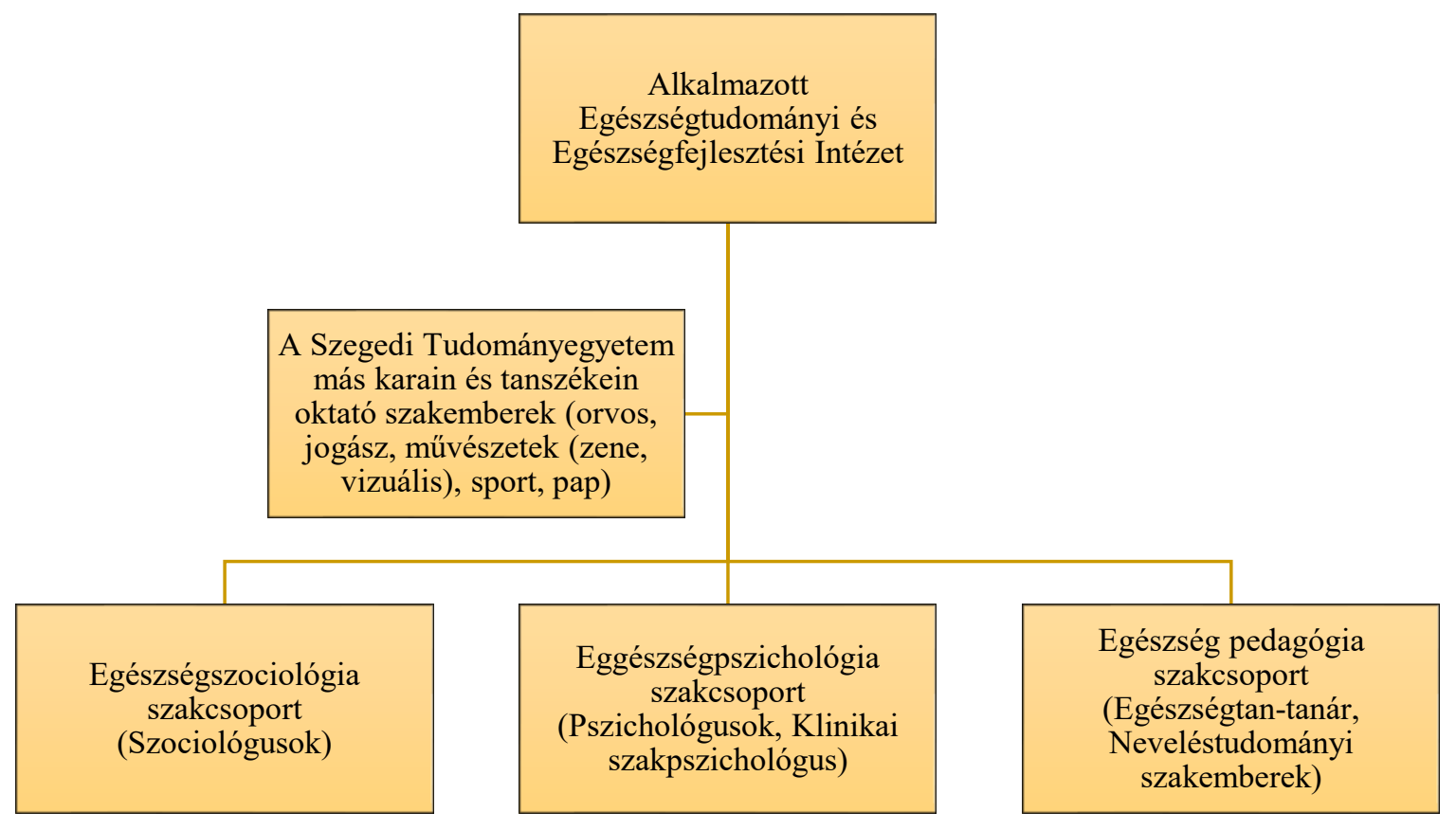

Forrás: Saját szerkesztés

A szakalapítási és szakindítási folyamat szinte permanensnek tekinthető intézetünkben. Ennek hátterében egyrészt a jogszabályi változások és a bennünket körülvevő társadalmi környezet igényei és elvárásai vannak, másrészt az intézeti közösségben folyamatos a megújulás igénye.

A felelős egyetemi kisközösség, aminek Intézetünket is tartjuk, igyekszik a saját szervezeti múködésében is alkalmazni a szervezetfejlesztésről vallott egészégfejlesztő ismereteket, nézeteket, módszereket. Ezek egyike az empowerment módszere. A módszer lényege úgy összegezhető az intézeti alkalmazásunkban, hogy ki mennyi feladatot, felelősséget delegál az intézeti hierarchiában, annyi elismerés illeti meg magát a munka elvégzőjét a feladat sikeres elvégzése után. Ez a módszer azontúl, hogy nagyon hatékony a szervezeten belül, az emberi kapcsolatokra is pozitív hatással van. A feladatok személyre szabott delegálásánál fontos annak a WHO elvnek az érvényesítése, hogy a „megfelelő ember a megfelelő helyen", azaz mindenkinek az erősségei - készségei, adottságai - épülnek be az adott munkafolyamatba. Ez a módszer hozzájárul a kreativitás kibontakoztatásához. Ennek egyik élő példája a legutóbbi intézeti összefogással megvaló- sított legújabb szak akkreditációnk is; a mentálhigiénés közösség- és kapcsolatépítő mesterszakot indította intézetünk 2019 szeptemberében.

Az Intézet előtt álló másik feladat az egységes osztatlan tanárképzés újraélesztése nyomán jelentkezett. Az egészségfejlesztés-tanár mesterszak indítására 2016-ban volt utoljára lehetőség. Aki az egészségfejlesztés területen tanár kíván lenni, az a 4+1 éves gyógytestnevelő-egészségfejlesztő osztatlan tanár szak elvégzésével teheti meg azt, mely szak csak a testnevelés tanár szakkal párosítható. Intézetünk szakmai koordinálásával megszületett a szakindítási anyag, amely az SZTE Szenátusa egyhangú támogatása mellett várja sorsát a MAB szakértői kezében.

Az egészségfejlesztés színvonalas múvelésének egyik nagyon fontos pillére a nemzetközi beágyazottság. Sikereinkben, képzési, kutatási eredményeinkben nagy szerepet játszottak és játszanak nemzetközi kapcsolataink, melyek Erasmus hallgatói és oktatói csereprogramok, nemzetközi tananyagfejlesztések, kutatási projektek, illetve konferenciakapcsolatok révén valósulnak meg. [5. ábra] 
5. ábra: Az Alkalmazott Egészségtudományi és Egészségfejlesztési Intézet nemzetközi tevékenységei

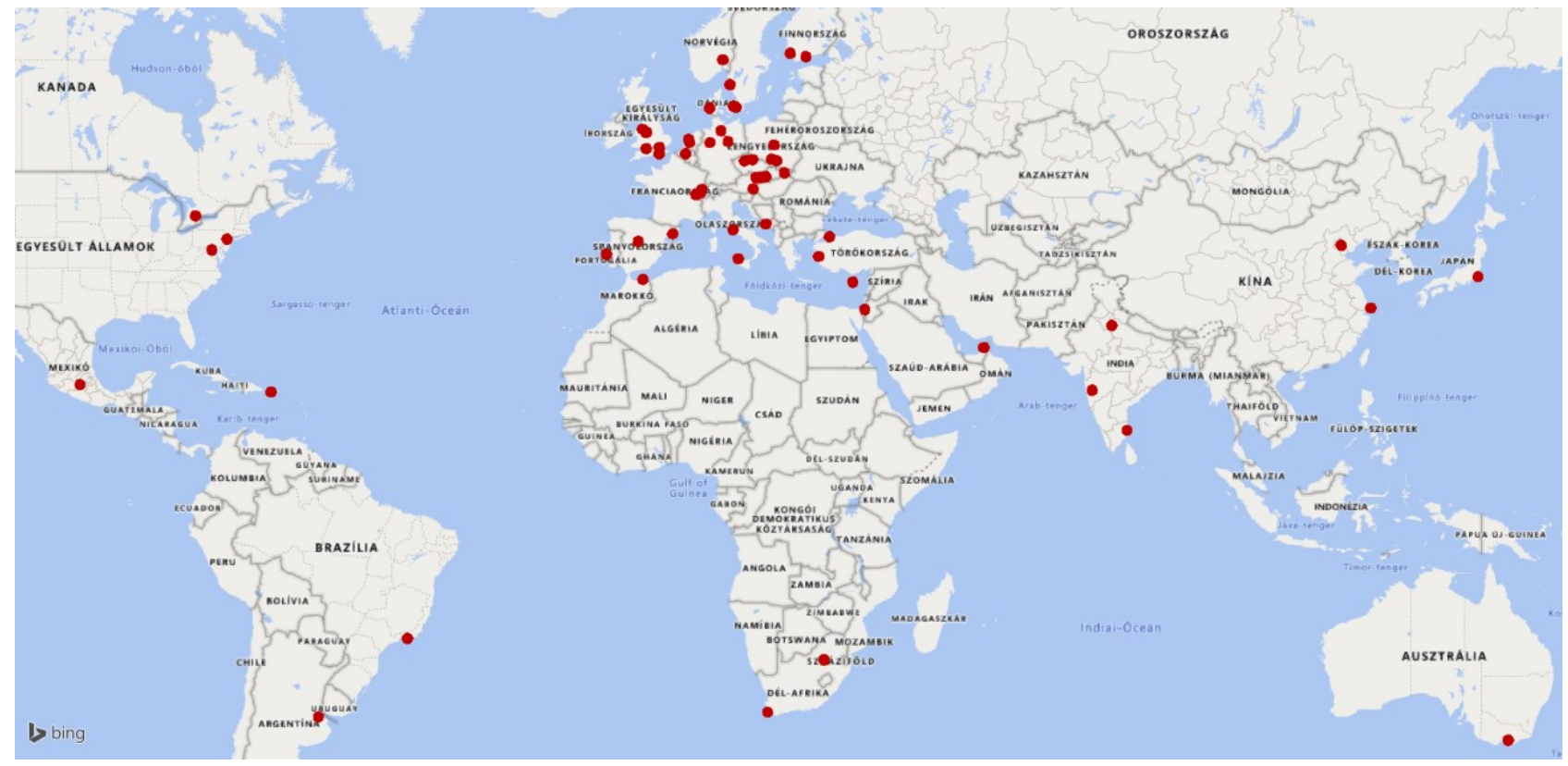

Forrás: Saját szerkesztés

Az Intézet az alábbi egyetemekkel tart fenn tartós, több éves munkakapcsolatot aktív Erasmus hallgatói és oktatói mobilitási és/vagy közös pályázati, publikációs tevékenység keretében: Universitat Bielefeld, Fakultät Gesundheitswissenschaften, Bielefeld, D; Escola Superior de Educacao de Lisboa, Lisszabon, PT; Turun Yliopisto, Turku, SF; Manchester Metropolitan University, MMU Cheshire, Crewe, UK; Fachhochschule JOANNEUM University of Applied Sciences, Bad Gleichenberg, A; University College Sealand, Soroe, DK; Brunel University West London, UK; Hochschule Magdeburg-Stendal (FH), D; Liverpool John Moore's University, UK; Leuphana Universität Lueneburg, Lueneburg, D; University of Silesia, Katowice, PL; Jagellonian University, Krakow, PL. University of Hradec Králové, CZ., Constantine the Philosopher University, Nitra, SK. 1,2

Intézetünk 2008 óta tagja a Nemzetközi Szociológiai Társaság (ISA) Aktív Szabadidőeltöltés kutatócsoportjának (RC13), melynek felkérésére Intézetünk rendezte meg nagy sikerrel a kutatócsoport 2013. évi nemzetközi konferenciáját Leisure, Health and Well-being címmel. Munkánk elismeréseként Dr. habil. Tarkó Klára 2014 és 2018 között általános elnökhelyettesként képviselte Intézetünket, jelenleg pedig kiemelt funkcióval rendelkező vezetőségi tag.
Az Ottawa Charta Egészségfejlesztő Iskolánk alapköve. Az Ottawa Charta 30 éves lett 2016-ban, melynek tiszteletére 2016.11.21.-25. Sanghaji, Kínában került megrendezésre a 9th Global Conference on Health Promotion. Promoting health, promoting sustainable development: It's our health, our future and our choice c. konferencia. A konferencián a világ minden országából csak delegált résztvevők vehettek részt. A legnagyobb megtiszteltetést jelentette számunkra, hogy ezen a történelmi eseményen a WHO genfi irodájának delegáltjaiként vehettünk részt. [6. ábra]

Intézetünk két nemzetközi - EU égisze alatt koordinált és finanszírozott - tananyagfejlesztési program szakmai koordinátora volt. Az egyikben a tanítóképzés részére dolgoztunk ki egészségnevelési, multikulturális, tehetséggondozó, nyelvi és képességfejlesztő programokat, a másikban a tanártovábbképzés tananyagát gazdagítottuk egészségfejlesztési tananyaggal távoktatás és papír-alapú formában, valamint foglalkoztunk a kisebbségekkel és a hátrányos helyzetű fiatalokkal. Mindkét pályázat a legmagasabb szintet jelölő 'A' minősítéssel zárult az EU minősítési rendszerében. Ezek a programok az alábbiak: 
6. ábra: Prof. Dr. Benkő Zsuzsanna és Dr. habil. Tarkó Klára a WHO genfi irodájának delegáltjai

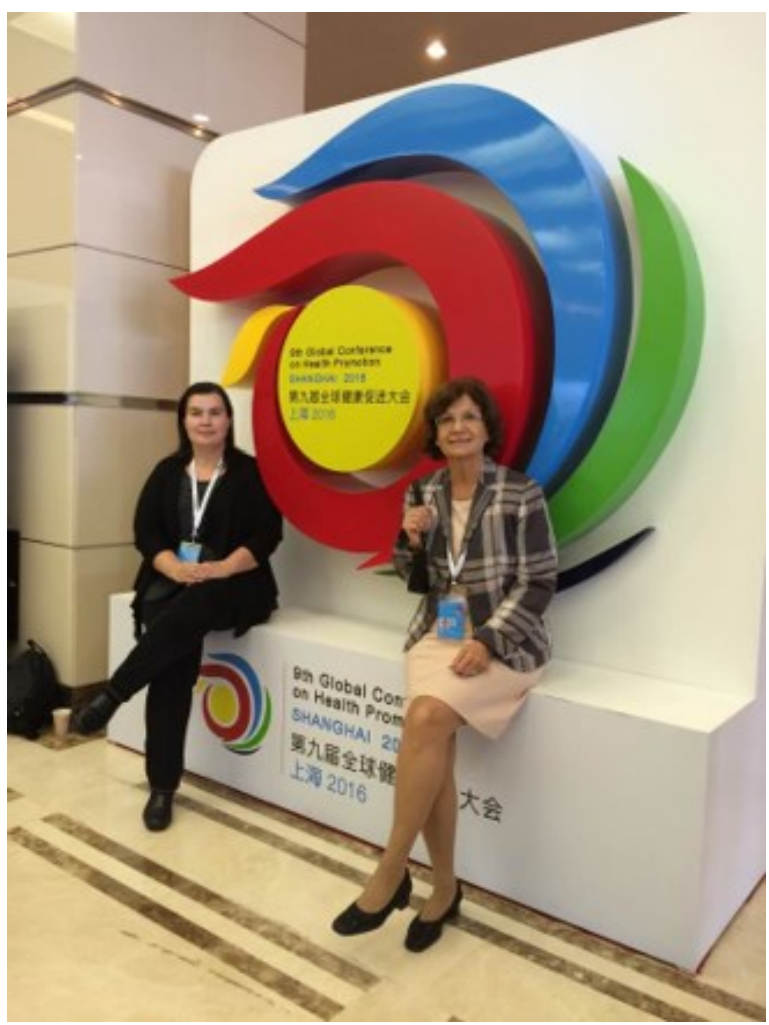

Forrás: Saját fotó

Integrált programok a tanítóképzés megújítása érdekében (Integrated programmes for lower primary teacher training). $2001-2004$.

Partnereink voltak:

Escola Superior de Educacao de Lisboa, Lisszabon, Portugália

Pädagogische Akademie des Bundes in Wien, Ausztria

A tanárok attitűdjének megváltoztatása a normál és a távoktatáson keresztül a nyitottabb emberi kapcsolatok érdekében (CANDOR - Changing the Attitude of teachers through Normal and Distance learning for Open human Relationships). 20022005.

Partnereink voltak:

Manchester Metropolitan University, Anglia

Universität Lüneburg, Németország

A nemzetközi team munka mellett jelentős hazai pályázatok keretében folytattunk tananyagfejlesztő tevékenységet. „A képzésből a munka világába való átmenet támogatása" elnevezésű Phare programon belül "A kisebbségi koordinátorok pedagógus szak- vizsga képzési programjának" kidolgozására került sor. A Nemzeti Népegészségügyi Program keretében 2005-ben, „Egészségfejlesztés oktatása a pedagógusképzés és a pedagógusok számára szervezett szakirányú továbbképzés keretében" címmel kiírt pályázatban az Alkalmazott Egészségtudományi Tanszék, a Szegedi Tudományegyetem Általános Orvostudományi Karának, illetve a Juhász Gyula Tanárképző Főiskolai Kar más tanszékeinek szakembereivel egy 30 órás egészségfejlesztési kurzust alakított ki.

Kutatási tevékenységünkön belül az egyik legnagyobb büszkeségünk a Visegrádi négyek országaiban végzett nagymintás életmódkutatásunk, melyben a családok táplálkozási, mozgási, szabadidős és kulturális szokásait térképeztük fel és vizsgáltuk a hagyomány, valamint a modernitás befolyását életmódválasztásaikra. Ebben partnereink voltak: Univerzita Konštantína Filozofa v Nitre. Faculta Socialnych Vied, Szlovákia; Univerzita Hradec Králové Ústav Socialnych Studií, Csehország; Universytet Slaski Instytut Socjologii, Lengyelország. 
A kutatási együttmúködésből oktatási együttmúködés született először egy közös kurzus keretében, majd pedig Erasmus bilaterális szerződések aláírásával.

A következőkben néhány további kutatásunkat is felsoroljuk, melyeket szintén értékeseknek tartunk.

- A holisztikus egészségfogalomnak megfeleltetett életmód-feltárás és összefüggései az Antonovsky-féle koherencia-érzettel, a SzegedCsanádi Egyházmegyében.

- Felkészülés a sikeres gyermekvállalásra (EFOP3.6.1-16-2016-00008)

- Hagyomány és modernitás a „Visegrádi országok" családjainak életmódjában, nemzetközi kutatás

- Lelki Egészség Felmérés Antonovsky egészségértelmezésének tükrében (empirikus kutatás Hódmezővásárhelyen; Csongrád-megye 7 járásában; a Szegedi Tudományegyetemen (TÁMOP6.1.5-14-2015-0004))

- Egészséges életmód kutatás 5. - 12. évfolyamos tanulók körében (empirikus kutatás a Dél-Alföldi régióban);

- PhD kutatások:

- Az olvasás, a tanulás és a metakogníció kapcsolata iskoláskorban.

- A fogyasztói döntéseket meghatározó pszichológiai tényezők feltárása, különös tekintettel az idői perspektíva és az önkontroll fogyasztói választásokban játszott szerepére.

- 20. század eleji családkép a közoktatás dokumentumaiban.

- A gyermekkori kötődési traumák és az antiszocialitás közötti összefüggések vizsgálata, különös tekintettel a családjukból kiemelten nevelkedők kötődési mintázatára, problémáira.

- Problémás mértékú internethasználat, az online agresszió és prevenciós lehetőségeik.

- A felsőoktatásban dolgozók egészségi állapotának és életmódjának vizsgálata és a munkahelyi egészségfejlesztés jelentőségének alátámasztása.

- Az egészség, lelki egészség vizsgálata összefüggésben a család-munka interferenciával.
- Az egyensúly eszméje a reformpedagógiában, mint ideáltipikus nevelési eszmerendszerben.

- Az egyensúlyi paraméterek vizsgálata.

Intézetünk munkatársai az MTMT tanulsága szerint több száz tanulmányt írtak, melyek egy része intézeti kiadványainkat gazdagítja:

http://www.jgypk.hu/tanszek/alkegeszseg/01 IntezetMenu/05Kiadvanyok/kiadvanyok.html

2013-ban egy újabb tételt pipáltunk ki az intézeti bakancslistán, hiszen elindítottuk folyóiratunkat Egész-Ség - Intézeti Hírmondó néven. Sokat gondolkoztunk azon, hogy milyen forma alkalmas arra, hogy a hírlevél, egy bárhol elérhető összekötő kapocsként, egy egészségfejlesztő közösség alapjává válhasson. Megjelent számainkban az intézetben folyó oktatói és hallgatói tevékenységről olvashat az érdeklődő. Az írások főként hallgatóink tollából születnek, elérhetősége:

http://www.jgypk.hu/tanszek/alkegeszseg/01 In-

tezetMenu/02Hirmondo/IntezetiHirmondo.html

Az Intézeti Hírmondó sikerén felbuzdulva 2016-ban újabb periodikát indítottunk útjára Terep Szemle címmel. Legyen szó bármelyik képzési programunkról: alapképzésről, tanári mesterképzésről, posztgraduális képzésről vagy pedagógus szakvizsgára felkészítő képzésről a terepgyakorlat mindegyikben kitüntetett jelentőségú. Ennek az az oka, hogy Intézetünkben a terepgyakorlatot olyan oktatási módszernek tekintjük, amely szakmailag irányított módon biztosít lehetőséget a hallgatók számára addigi tanulmányaik inter- és multidiszciplináris alkalmazására - valós egészségfejlesztési feladatok megvalósítása során. A terepgyakorlat múhelymunka, melynek keretében a hallgató egyre önállóbban képes alkalmazni a képzésben megszerzett tudását, mégpedig valódi közösségekben, valódi emberekkel, az egészségfejlesztési feladatok valódi szakmai és etikai felelősségének birtokában. A terepgyakorlat időben, feladatban lépcsőzetesen felépített rendszerben valósul meg, amely a hallgatónak és a terepgyakorlat résztvevőinek egyaránt biztonságot nyújt, hogy 'kipróbálja' az egészségfejlesztés egy-egy megvalósulási formáját, mint pl. életmódtanácsadás, egészségnap vagy játékos családi nap. Ez a hallgatónak és a munkát kísérő 
oktatónak egyaránt embert próbáló feladat, azonban - véleményünk szerint megéri a befektetést. Az elmúlt évek terepgyakorlati munkáinak beszámolói arról győztek meg bennünket, hogy a tapasztalatok szerkesztett közzétételével mindenki gazdagodik: a hallgató, az oktató, a résztvevők és maga az egészségfejlesztő szakma is. Terep Szemle címú kiadványunkban ezt a 'hozadékot' tesszük közkincsé. $^{3}$

Az oktató-, kutatómunka, a rendszeres nemzetközi jelenlét mellett Intézetünk nagy hangsúlyt fektet a hallgatók tehetséggondozására. Minden évben többen is megmérettetik magukat a Tudományos Diákköri terepen, népszerűsítik társaik körében a tudományos kutatómunkát és múhely keretében dolgoznak együtt témavezetőikkel. ${ }^{2}$

Intézetünk személyi állományát jelenleg 1 profeszszor emerita, 1 főiskolai tanár, 2 főiskolai docens,
2 adjunktus, 2 tanársegéd, 2 mesteroktató, 1 gyakorlati oktatást segítő munkatárs és 1 intézeti munkatárs alkotja, a szakcsoporti rendszer pedig átalakult 1 tanszék és 1 szakcsoport összetételüvé. [7. ábra] Szakmai összetételünk maradéktalanul megfelel - országos és nemzetközi szinten is egyedülálló módon - annak a WHO elvárásnak, ami szerint az egészségfejlesztés alapja három tudományterület: szociológia, pszichológia, medicina. A szociológia és a pszichológia mellett a neveléstudományt is több oktatónk képviseli alap, mester és PhD szinten is. Ezt a pedagógusképzéseink okán is fontosnak tartjuk. A medicina területén az Általános Orvostudományi Karral több szinten ápolt hagyományos kapcsolat a biztosíték. Intézeti összetételünk ékes bizonyítéka annak a ténynek, hogy egy ilyen csapat több mint a tagjai összessége, együtt, többirányú tudásunk, képességeink összeadódásával képezzük azt a minőségi szintet, amely országosan és nemzetközileg is kiemelkedő szakmai erőforrás.

\section{7. ábra: Az Alkalmazott Egészségtudományi és Egészségfejlesztési Intézet jelenlegi struktúrája a} Juhász Gyula Pedagógusképző Kar organogramjában

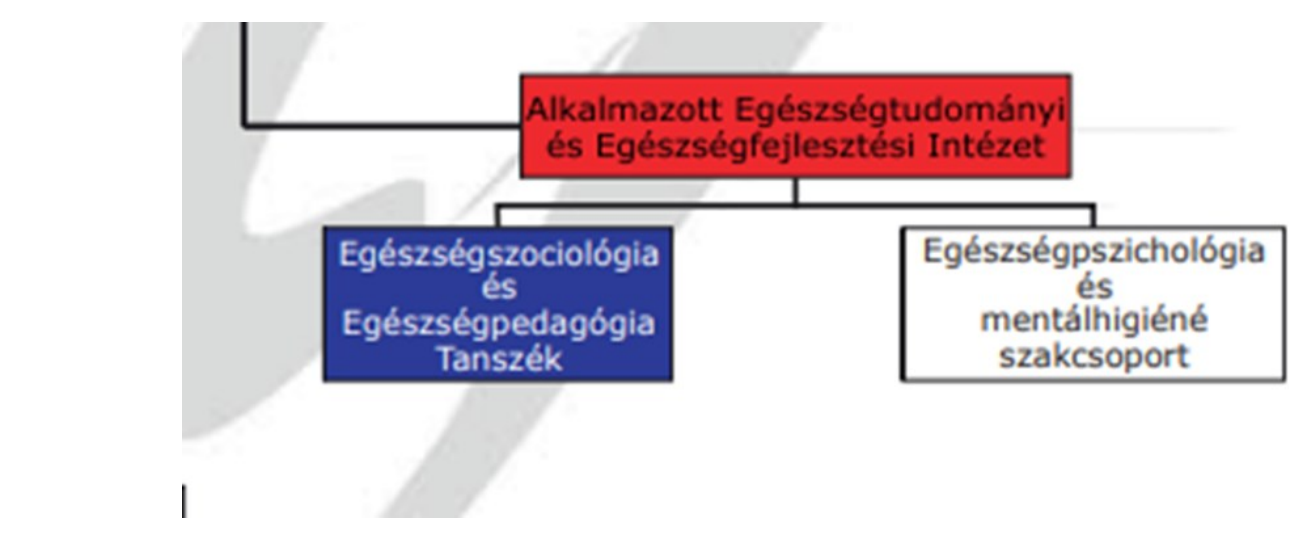

Forrás: részlet a SZTE JGYPK organogramjából

Az Intézet munkatársai jelenleg:

Dr. habil. Tarkó Klára, intézetvezető, tanszékvezető főiskolai tanár

Prof. Dr. Benkő Zsuzsanna, Professzor Emerita Dr. Lippai László Lajos, szakcsoportvezető főiskolai docens

Dr. Pálmai Judit, adjunktus

Dr. Prievara Dóra Katalin, adjunktus

Dr. Osváth Viola, főiskolai docens

Kis Bernadett, mesteroktató

Mátó Veronika, mesteroktató

Mihálka Mária, tanársegéd
Nádudvari Gabriella, tanársegéd

Pósa Gabriella, gyakorlati oktatást segítő

munkatárs

Galacné Kaló Tímea, tanácsos, intézeti munkatárs

Carl Gustav Jung szerint „Egy adott időpontban született dolog magán viseli a pillanat valamennyi sajátosságát." Úgy gondoljuk, ez a pillanat Intézetünk esetében a legkedvezőbb csillagzat alatt jött el, így nagy dolgok vártak és várnak továbbra is ránk a következő 25 évben is. 


\section{HIVATKOZÁSOK}

${ }^{1}$ Benkő Zs. Erdei K. Egészségfejlesztés felsőfokon. Szeged: JGYF Kiadó, 2003.

${ }^{2}$ Tarkó K. Egészségfejlesztés továbbra is felsőfokon. In. Tarkó K., Lippai L. (editors):

„Gyümölcs? A fa beváltja azt, amit virágával igért." Tanulmányok Benkő Zsuzsanna 60. születésnapjára.

SZTE JGYPK Alkalmazott Egészségtudományi és Egészségfejlesztési Intézet, Szeged, 2013.

${ }^{3}$ Lippai L. Előszó. Terep Szemle.

http://www.jgypk.hu/tanszek/alkegeszseg/01 IntezetMenu/10TerepSzemle/Terep Szemle.html, 2016. 